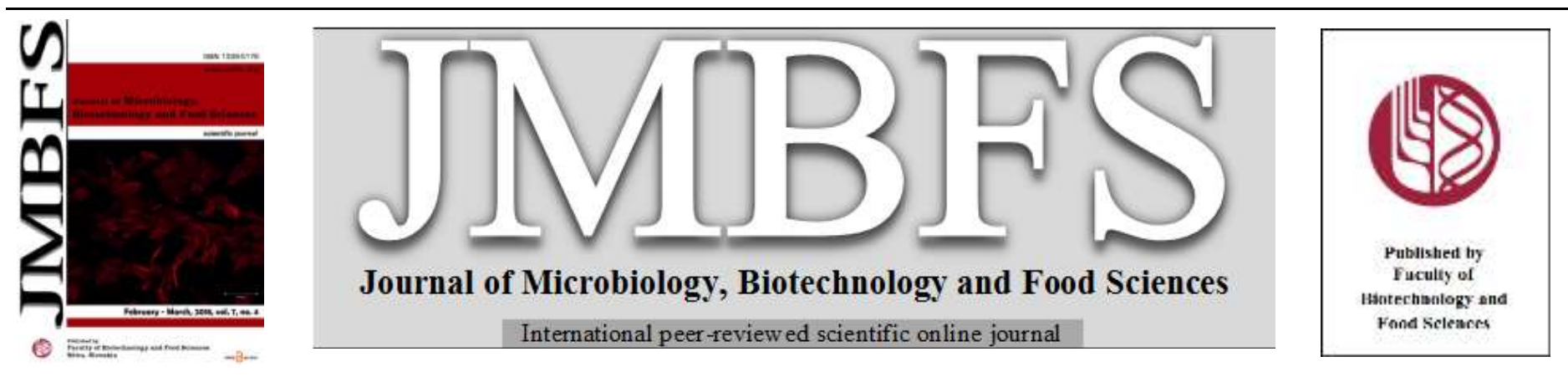

\title{
PROXIMATE COMPOSITION, ACCEPTABILITY AND STABILITY OF PROBIOTIC DAIRY YOGHURT CONTAINING COOKING BANANA/MATOOKE PUREE AND Lactobacillus rhamnosus yoba
}

\author{
Ivan Muzira Mukisa ${ }^{\text {* }}$ and Shamim Warugaba Birungi ${ }^{2}$ \\ Address(es): Dr. Ivan Muzira Mukisa, \\ ${ }^{1}$ Department of Food Technology and Nutrition, Makerere University, P.O. Box 7062, Kampala, Uganda, Tel: +256 775414537. \\ ${ }^{2}$ Department of Food Technology and Nutrition, Makerere University, P.O. Box 7062, Kampala, Uganda, Tel: +256703330933.
}

*Corresponding author: ivanmukisa@caes.mak.ac.ug; ivanmukisa@gmail.com

doi: 10.15414/jmbfs.2018.7.4.343-347

ARTICLE INFO

Received 20.6. 2017

Revised 19. 10. 2017

Accepted 20.11.2017

Published 1. 2. 2018

$\underline{\text { Regular article }}$

orten access

\begin{abstract}
Cooking bananas/matooke are eaten in the unripe state but quickly ripen leading to postharvest losses. The purpose of this study was to develop fruit-based probiotic dairy yoghurt using ripe matooke and Lactobacillus rhamnosus yoba. Yoghurt mixtures containing varying proportions of matooke $(0 \%, 5 \%, 7.5 \%$ and $10 \%)$ were fermented at room temperature for 32 hours. Acidity, $\mathrm{pH}$ and counts of Lactobacillus rhamnosus were determined during fermentation and storage $\left(4^{\circ} \mathrm{C}\right.$ for three weeks). Consumer acceptability was determined at weekly intervals. Lactobacillus rhamnosus counts increased from $7-9 \log \mathrm{cfu}_{\mathrm{g}} \mathrm{g}^{-1}$ after 24 hours of fermentation. Banana accelerated the acidification rate with banana yoghurts attaining $\mathrm{pH}=4.4-4.5$ and acidity of $0.60-0.67 \%$ in 24 hours. The control took 32 hours to attain a $\mathrm{pH}=4.5$. Ripe cooking banana introduced a slight banana aroma but did not significantly $(\mathrm{p}>0.05)$ affect consumer acceptability. Yoghurt containing $7.5 \%$ banana was most acceptable and contained: $148 \mathrm{kcal} 100 \mathrm{~g}^{-1}, 76.81 \%$ moisture, $12.37 \%$ carbohydrates, $6.18 \%$ protein, $3.35 \%$ fat, $0.77 \%$ ash and $1.04 \%$ calcium. Yoghurt with $7.5 \%$ banana was stable at $4{ }^{\circ} \mathrm{C}$ for 21 days and maintained viable counts above the target of $\log 6 \mathrm{cfu}^{-1} \mathrm{~g}^{-1}$. This study showed that an acceptable fruit based probiotic yoghurt can be produced by adding ripe banana to the yoghurt mix.
\end{abstract}

\section{INTRODUCTION}

Probiotics are 'live microorganisms which when administered in adequate amounts confer a health benefit to the consumer' (FAO/WHO, 2002). There is increasing global interest in the use of probiotics owing to the range of associated health benefits. Lactobacillus rhamnosus GG (LGG) is a widely studied probiotic that is beneficial in the treatment of gastrointestinal diseases (Guandalini, 2011; Horvath et al., 2011). LGG reduces the duration of rotavirus-associated diarrhea, a major health concern in children in Uganda and several developing countries (Guandalini, 2011; Nakawesi et al., 2010). However, access to affordable probiotics and acceptable food carriers are major challenges for adoption of probiotics in Africa (Franz et al., 2014). Generic forms of probiotics, such Lactobacillus rhamnosus yoba (a generic form of LGG), can be used to increase access to probiotics in Uganda and other developing countries (Kort and Sybesma, 2012). Locally consumed foods in Uganda, such as yoghurt and banana, can be evaluated as probiotic carriers for Lactobacillus rhamnosus yoba. Yoghurt is a product of the lactic fermentation of milk by starter cultures, resulting in a $\mathrm{pH}$ drop to $\leq 4.6$ (Tamime, 2002). Streptococcus thermophilus and Lactobacillus delbrueckii subsp. bulgaricus are the major symbiotic starter cultures used (Codex Alimentarius, 2003). A mixed starter culture of Lactobacillus rhamnosus yoba and Streptococcus thermophilus C106 has also been used to ferment dairy yoghurt, Mutandabota (baobab pulp and milk), and cereal beverages such as Obushera, Uji and Zom Kom (Kort et al., 2015). Lactobacillus rhamnosus yoba is unable to degrade lactose and casein in milk while Streptococcus thermophilus $\mathrm{C} 106$ has the ability and thus inclusion of the latter facilitates growth of the probiotic in dairy products (Kort et al., 2015).

Yogurt is among the most common dairy products consumed around the world (Saint-Eve et al., 2006) and is also commonly used as a probiotic carrier (Franz et al., 2014). In Uganda, yoghurt is popular amongst all social classes (Balikowa, 2011) and is thus a potentially acceptable carrier for probiotics targeting the Ugandan market. The Ugandan market has two types of yoghurt: set and stirred yoghurts, although the latter is more common (Mukisa and Kyoshabire, 2010). Most of the brands are flavored with synthetic flavorants while very few contain dried fruit pieces.
The demand for fruity yoghurts with different flavours has been on the rise because fruits and fruit flavours significantly increase yoghurt consumption among all age groups (Chandan, 2011). Fruit preparations are commonly added to yoghurt formulations at levels of $10-15 \%$, which should ideally cause minimal or no negative effects on the product's aesthetic appeal (Chandan, 2014).

The cooking banana/matooke (Musa spp. AAA-EA group) is extensively grown in Uganda (Karamura et al., 1998). It is highly perishable and is generally eaten in cooked form before ripening (Karamura et al., 1998). About $22-45 \%$ of matooke is lost during peak production seasons due to the rapid ripening, inadequate storage and transportation, and lack of alternative food processing options (Muranga et al., 2010). Raw matooke has been evaluated for use in bread making (Muranga et al., 2010) and in development of complementary foods (Muranga et al., 2009; Muranga et al., 2011). However, there are no known studies on the utilization of ripe matooke in any value addition processes such as production of fruit based dairy yoghurts. Lactobacillus rhamnosus yoba has previously been used to produce an acceptable fruit yoghurt-like product called Mutandabota, which contains $14 \%$ baobab fruit in milk (Mpofu, 2015).

The objective of this study was to utilize ripened matooke in the production of probiotic dairy yoghurt containing Lactobacillus rhamnosus yoba. We evaluated the effect of banana concentration on growth of Lactobacillus rhamnosus and acceptability of the yoghurt. Proximate composition and shelf stability of the most acceptable banana yoghurt formulation were also determined. Using ripe matooke in fruit yoghurt production can reduce postharvest losses of matooke. The probiotic banana yoghurt developed can be targeted at children to help prevent or manage diarrhea.

\section{MATERIALS AND METHODS}

\section{Milk, sugar and banana}

Pasteurized milk (Jesa Dairy Ltd, Uganda) and brown sugar (Kakira Sugar Ltd, Jinja Uganda) were purchased from Tusky's supermarket, Makerere, Kampala. Fresh unripe matooke were purchased from the Kasubi market, Kampala and allowed to ripen at room temperature for five days. 


\section{Starter culture}

The probiotic starter culture comprising of Lb. rhamnosus yoba 2012 and Streptococcus thermophilus C106 (Kort et al., 2015) was obtained from the Yoba for Life Foundation (Amsterdam, The Netherlands) and stored at $-40^{\circ} \mathrm{C}$ prior to subsequent use. The starter culture was prepared by following the manufactures instructions. One liter of milk was pasteurized at $85^{\circ} \mathrm{C}$ for 15 minutes, cooled to $45^{\circ} \mathrm{C}$, inoculated with $1 \mathrm{~g}$ of starter culture and incubated for 12 hours in a thermos flask.

\section{Production of probiotic fruit yoghurt containing ripened cooking banana}

Control yoghurt and banana yoghurt were produced by mixing milk, ripe cooking banana and sugar in different proportions (Table 1). The ingredient were blended to a uniform mixture using a blender (Sayona, Patissies, China) The mixture was then pasteurized at $85^{\circ} \mathrm{C}$ for 15 minutes and cooled to $45^{\circ} \mathrm{C}$ using a cold water bath prior to prior to inoculation with $2 \%$ freshly prepared starter culture. Incubation was carried out at room temperature. Samples were taken at $\mathrm{t}=0,6,12,24$ and 32 hours during fermentation for analysis. At the end of fermentation the probiotic yoghurt was stored at $4^{\circ} \mathrm{C}$ for a period of 3 weeks Samples were taken weekly intervals to determine product stability and viability of the probiotic starter. Two independent fermentations were carried out for each formulation.

Table 1 Formulations used for preparing banana yoghurts containing ripe cooking banana

\begin{tabular}{lccc}
\hline Yoghurt formulation & \multicolumn{3}{c}{ Amount of different raw materials (g) } \\
\cline { 2 - 4 } & Milk & Ripe cooking banana & Sugar \\
\hline 0\% banana - control & 900 & 0 & 100 \\
5\% banana & 850 & 50 & 100 \\
$7.5 \%$ banana & 825 & 75 & 100 \\
10\% banana & 800 & 100 & 100 \\
\hline
\end{tabular}

\section{Analyses}

\section{Physico-chemical analyses}

The $\mathrm{pH}$ of yoghurt was determined using a digital $\mathrm{pH}$ meter (Dr. Meter, model pH-100, Yantai Dongrun Instrument Co. Ltd, Shandong, China) calibrated with standard buffers of $\mathrm{pH}=4.00$ and 6.86. Total soluble solids ( ${ }^{\circ}$ Brix at room temperature) were determined using a hand refractometer (RSG-100/ATC, Sino Science and Technology Co. Ltd, Zhangzhou, China). Total titratable acidity was determined by titrating $10 \mathrm{ml}$ of each sample against standardized $0.1 \mathrm{M}$ sodium hydroxide (AOAC, 1995).

\section{Proximate composition}

Proximate composition was only determined for the most acceptable formulation and the control yoghurt. Dry matter was determined using the oven method at $100^{\circ} \mathrm{C}$ for 24 hours (AOAC, 2000). Ash content was determined by igniting in a muffle furnace at $550{ }^{\circ} \mathrm{C}$ for 6 hours (AOAC, 2000). Crude protein was determined by the Kjeldahl method (AOAC, 2000) using a conversion factor of
6.38 (Codex Alimentarius, 2003). Total Carbohydrate was determined using the phenol-sulfuric acid for total carbohydrate (AOAC, 2000). Crude fiber was determined following acid and alkali digestion (AOAC, 2000). Crude fat was determined using Soxhlet extraction while gross energy content was determined by oxygen bomb calorimeter (Gallenkamp Autobomb, UK) (AOAC, 2000).

\section{Microbiological analyses}

Serial dilutions of the yoghurt samples were prepared using $1 / 4$ strength ringer's solution (Merck KGaA, Dermstadt, Germanty). Lactobacillus rhamnosus count were determined by plating selected dilutions in De Man Rogosa Sharpe agar (Laboratorios Conda, Asiagel, Spain) and incubating anaerobically at $37^{\circ} \mathrm{C}$ for 2 days. Yeasts and molds counts were determined after plating in Potato Dextrose Agar (Laboratorios Conda, Asiagel, Spain) and incubating at room temperature for 5 days. Microbial counts were determined at 0 and 24 hours of fermentation and at $0,1,2$ and 3 weeks during refrigeration storage at $4^{\circ} \mathrm{C}$

\section{Sensory evaluation}

An untrained consumer panel $(n=40)$ was used to determine the consumer acceptability of the four different formulations of banana yoghurt. Sensory evaluation was carried out in individual booths in the sensory evaluation laboratory at the Department of Food Technology and Nutrition, Makerere University. Panelists ranked acceptability of various sensory attributes using a 9 point hedonic scale $(9=$ like extremely, $8=$ like very much, $7=$ like moderately, 6 $=$ like slightly, $5=$ neither like nor dislike, $4=$ dislike slightly, $3=$ dislike moderately, 2 = dislike very much, $1=$ dislike extremely). Panelists also expressed their willingness to regularly purchase each of the yoghur formulations using a 5 point Likert scale $(5=$ strongly agree, $4=$ agree, $3=$ not decided, 2 = disagree, 1 = strongly disagree). To evaluate the shelf life, a panel of 10 members was used to assess any changes in score the acceptability of different attributes and willingness to purchase the yoghurt as described earlier.

\section{Statistical analysis}

Means of two treatments were subjected to a two sample t-test while means of more than two treatments were subjected to one way analysis of variance (ANOVA) to test for significant differences at a 5\% level of significance. The least significant difference test (Fisher's LSD) was used to determine means that were significantly different from one another after the ANOVA test. Al statistical analyses were performed by XLSTAT (2010, Addinsoft, Paris, France).

\section{RESULTS}

\section{Fermentation of banana yoghurts by Lactobaillus rhamnosus yoba}

Lactobacillus rhamnosus yoba propagated well and fermented all four banana yoghurt formulations used in this study. Cells counts increased significantly ( $\mathrm{p}<$ 0.05 ) from about $7 \log \mathrm{cfu} . \mathrm{g}^{-1}$ to $9 \log \mathrm{cfu} . \mathrm{g}^{-1}$ after 24 hours of fermentation (Table 2). Yeasts and moulds were not detected in any of the samples.

Table 2 Changes in Lactobacillus rhamnosus yoba counts during fermentation of yoghurt containing differen concentrations of ripe cooking banana/matooke

\begin{tabular}{|c|c|c|c|c|}
\hline \multirow[b]{2}{*}{ Time (h) } & \multicolumn{4}{|c|}{ Cell counts ( $\mathrm{Log}_{\mathrm{cfu}} \mathrm{g}^{-1}$ in different formulations of banana yoghurt) } \\
\hline & 0\% banana - Control & $5 \%$ banana & $7.5 \%$ banana & $10 \%$ banana \\
\hline 0 & $7.22 \pm 0.04^{\mathrm{a}}$ & $7.25 \pm 0.18^{\mathrm{a}}$ & $7.13 \pm 0.18^{\mathrm{a}}$ & $7.21 \pm 0.27^{\mathrm{a}}$ \\
\hline 24 & $9.81 \pm 0.16^{\mathrm{b}}$ & $9.50 \pm 0.58^{\mathrm{b}}$ & $9.94 \pm 0.03^{b}$ & $9.56 \pm 0.59^{\mathrm{b}}$ \\
\hline p-value & 0.002 & 0.034 & 0.002 & 0.036 \\
\hline
\end{tabular}

Results are means \pm standard deviations of two independent fermentations. Means in the same column with different superscripts $(\mathrm{a}$ and $\mathrm{b})$ are significantly different $(\mathrm{p}<0.05)$

Growth of $L b$. rhamnosus yoba in banana yoghurts was accompanied by a decrease in $\mathrm{pH}$ from 6.13 to $4.32-4.49$ and increase in acidity from 0.22 to 0.64 - $0.66 \%$ after 32 hours of fermentation (Figure 1). Increasing banana concentration in the formulation significantly $(\mathrm{p}<0.05)$ increased the rate of acidification. However, the final acidity of the four yoghurt formulations was not significantly $(\mathrm{p}>0.05)$ different. Yoghurt with $10 \%$ banana attained a $\mathrm{pH}$ of less than 4.5 in 24 hours 


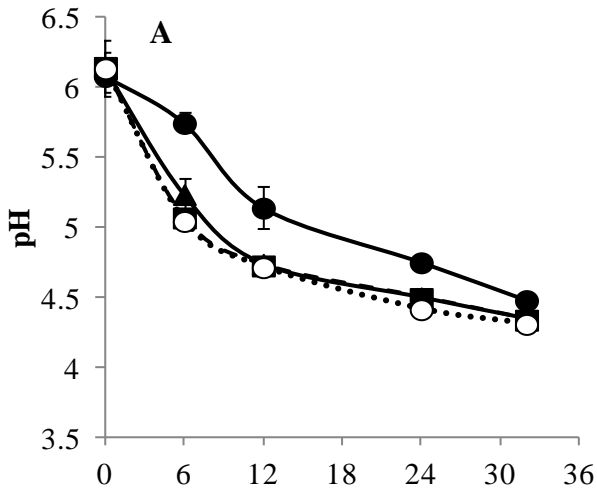

Time (hours)

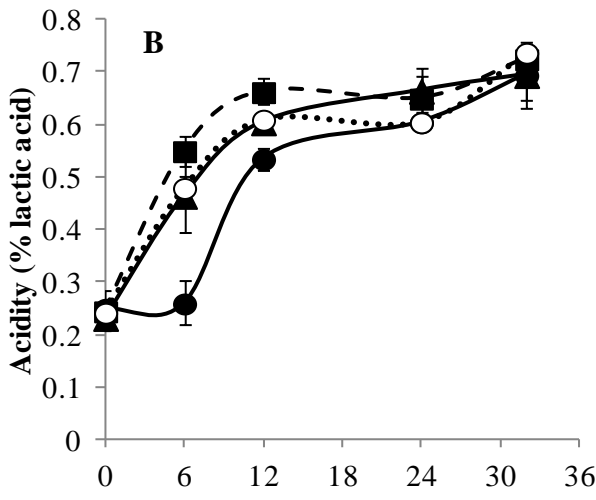

Time (hours)

\section{$\longrightarrow 0 \%$ banana -control $\longrightarrow 5 \%$ banana - - $-7.5 \%$ banana $\cdots . \cdot 10 \%$ banana}

Figure 1 Changes in $\mathrm{pH}$ (A) and acidity (B) during the fermentation banana yoghurts Error bars show standard deviations of two independent fermentations.

\section{Effect of banana concentration on acceptability of banana yoghurt}

Generally all the banana yoghurt formulations were accepted by the consumers (Table 3 ). Banana concentration significantly $(\mathrm{p}<0.05)$ affected the acceptability scores of appearance, taste, overall acceptability and the purchase index. Yoghurt with $7.5 \%$ banana received the highest scores for all parameters evaluated. The purchase index, appearance and taste scores of yogurts containing 5\% and $7.5 \%$ banana were not significantly different from those of control yoghurt. Addition of banana had no significant $(\mathrm{p}<0.05)$ effect on the acceptability of aroma and mouthfeel. Panelists generally noted that the banana yogurt samples had a slight banana aroma, were relatively thick and smooth.

Table 3 Effect of ripe banana on the acceptability and purchase index of yoghurt

\begin{tabular}{lcccccc}
\hline \multirow{2}{*}{$\begin{array}{c}\text { Yoghurt } \\
\text { formulation }\end{array}$} & \multicolumn{5}{c}{ Acceptability scores } & Purchase Index \\
\cline { 2 - 5 } & Appearance & Taste & Aroma & Mouthfeel & Overall Acceptability \\
\hline $0 \%$ banana- Control & $5.8 \pm 1.8^{\mathrm{b}}$ & $6.2 \pm 1.5^{\mathrm{ab}}$ & $6.3 \pm 1.4^{\mathrm{a}}$ & $5.8 \pm 1.8^{\mathrm{a}}$ & $6.1 \pm 1.5^{\mathrm{ab}}$ & $3.2 \pm 1.2^{\mathrm{ab}}$ \\
$5 \%$ banana & $6.6 \pm 1.4^{\mathrm{ab}}$ & $6.3 \pm 1.9^{\mathrm{ab}}$ & $6.3 \pm 1.5^{\mathrm{a}}$ & $6.4 \pm 1.7^{\mathrm{a}}$ & $6.6 \pm 1.4^{\mathrm{ab}}$ & $3.4 \pm 1.1^{\mathrm{ab}}$ \\
$7.5 \%$ banana & $7.1 \pm 1.2^{\mathrm{a}}$ & $6.7 \pm 1.6^{\mathrm{a}}$ & $6.3 \pm 1.8^{\mathrm{a}}$ & $6.7 \pm 1.7^{\mathrm{a}}$ & $6.8 \pm 1.5^{\mathrm{a}}$ & $3.8 \pm 1.2^{\mathrm{a}}$ \\
$10 \%$ banana & $6.1 \pm 1.8^{\mathrm{b}}$ & $5.7 \pm 1.8^{\mathrm{b}}$ & $5.6 \pm 2.0^{\mathrm{a}}$ & $5.9 \pm 1.8^{\mathrm{a}}$ & $5.8 \pm 1.4^{\mathrm{b}}$ & $3.0 \pm 1.4^{\mathrm{b}}$ \\
p-value & 0.002 & 0.053 & 0.205 & 0.091 & 0.018 & 0.037 \\
\hline
\end{tabular}

Values are means \pm standard deviations $(\mathrm{n}=40$ panelists). Values in the same column with different superscripts $(\mathrm{a}, \mathrm{b})$ are significantly different $(\mathrm{p}<$ 0.05 ). For acceptability scores the interpretation of the anchors on the 9 point hedonic scale used are as follows: $9=$ like extremely, $8=$ like very much, 7 = like moderately, $6=$ like slightly, $5=$ neither like nor dislike, $4=$ dislike slightly, $3=$ dislike moderately, $2=$ dislike very much, $1=$ dislike extremely. A 5 point Likert scale was used for the purchase index/willingness to buy (anchors: 1 - strongly disagree, 2 - disagree, 3 - not decided, $4-$ agree and 5 - strongly agree).

Effect of addition of ripe banana on the nutritional composition of yoghurt The nutrition composition of the most acceptable banana yoghurt formulation (7.5\% banana) was compared to that of control yoghurt (Table 4). Addition of banana up to $7.5 \%$ did not significantly $(\mathrm{p}>0.05)$ affect the energy content, carbohydrate, protein, fat, fiber, ash and calcium content of yoghurt but caused a slight and significant $(\mathrm{p}<0.05)$ reduction in moisture content.

Table 4 Effect of ripe banana on the nutrient composition of yoghurt

\begin{tabular}{|c|c|c|c|}
\hline \multirow[b]{2}{*}{ Component } & \multicolumn{2}{|c|}{ Content of nutrients in yoghurt } & \multirow[b]{2}{*}{ p-value } \\
\hline & $\begin{array}{c}0 \% \text { banana - } \\
\text { control }\end{array}$ & $7.5 \%$ banana & \\
\hline Energy (Kcal.100 g $\left.{ }^{-1}\right)$ & $129.19 \pm 7.27^{\mathrm{a}}$ & $148.00 \pm 0.65^{\mathrm{a}}$ & 0.068 \\
\hline Moisture (\%) & $77.63 \pm 0.10^{\mathrm{a}}$ & $76.81 \pm 0.09^{\mathrm{b}}$ & 0.013 \\
\hline Carbohydrates $(\%)$ & $10.73 \pm 0.75^{\mathrm{a}}$ & $12.37 \pm 0.06^{\mathrm{a}}$ & 0.092 \\
\hline Protein $(\%)$ & $5.95 \pm 0.001^{\mathrm{a}}$ & $6.18 \pm 0.14^{\mathrm{a}}$ & 0.142 \\
\hline Fat $(\%)$ & $3.71 \pm 0.18^{\mathrm{a}}$ & $3.35 \pm 0.11^{\mathrm{a}}$ & 0.145 \\
\hline Fiber $(\%)$ & $0.00^{\mathrm{a}}$ & $0.07 \pm 0.05^{\mathrm{a}}$ & 0.194 \\
\hline Ash $(\%)$ & $0.73 \pm 0.08^{\mathrm{a}}$ & $0.77 \pm 0.09^{\mathrm{a}}$ & 0.731 \\
\hline Calcium (\%) & $1.07 \pm 00^{\mathrm{a}}$ & $1.04 \pm 0.02^{\mathrm{a}}$ & 0.127 \\
\hline
\end{tabular}

Results are means \pm standard deviations of two independent fermentations. Values in the same row with the same superscripts $(a, b)$ are not significantly different $(\mathrm{p}>0.05)$

\section{Shelf stability of probiotic yoghurt containing $7.5 \%$ ripe banana}

Probiotic banana yoghurt was generally stable during storage at $4{ }^{\circ} \mathrm{C}$ for three weeks in terms of $\mathrm{pH}$, acidity and overall consumer acceptability (Table 5).

Values of $\mathrm{pH}(4.32-4.49)$, acidity $(0.61-0.81)$ and overall acceptability $(7.3-$

7.7 ) did not vary significantly $(\mathrm{p}>0.05)$. Cell counts of $L b$. rhamnosus yoba reduced significantly $\left(9.95-6.25 \log \mathrm{cfu}_{\mathrm{g}} \mathrm{g}^{-1}\right)$ during storage but remained above $6.0 \log$ cfu. $\mathrm{g}^{-1}$. Yeasts and moulds were not detected in any of the samples.

Table 5 Changes in $\mathrm{pH}$, titratable acidity, microbial counts and overall acceptability of probiotic yoghurt containing $7.5 \%$ ripe banana during storage at $4^{\circ} \mathrm{C}$

\begin{tabular}{lcccc}
\hline $\begin{array}{l}\text { Storage } \\
\text { time } \\
\text { (weeks) }\end{array}$ & $\mathbf{p H}$ & $\begin{array}{c}\text { Acidity } \\
\text { (\% lactic } \\
\text { acid) }\end{array}$ & $\begin{array}{c}\text { Lb. } \\
\text { rhamnosus } \\
\text { cell counts } \\
(\text { Log cfu. }\end{array}$ & $\begin{array}{c}\text { Overall } \\
\text { acceptability } \\
\text { score }\end{array}$ \\
\hline 0 & $4.49 \pm 0.01^{\mathrm{a}}$ & $0.65 \pm 0.04^{\mathrm{a}}$ & $9.95 \pm 0.03^{\mathrm{a}}$ & $7.7 \pm 0.9^{\mathrm{a}}$ \\
1 & $4.32 \pm 0.06^{\mathrm{a}}$ & $0.81 \pm 0.10^{\mathrm{a}}$ & $7.34 \pm 0.28^{\mathrm{c}}$ & $7.6 \pm 0.9^{\mathrm{a}}$ \\
2 & $4.34 \pm 0.01^{\mathrm{a}}$ & $0.70 \pm 0.04^{\mathrm{a}}$ & $8.07 \pm 0.03^{\mathrm{b}}$ & $7.4 \pm 1.0^{\mathrm{a}}$ \\
3 & $4.38 \pm 0.01^{\mathrm{a}}$ & $0.61 \pm 0.03^{\mathrm{a}}$ & $6.25 \pm 0.15^{\mathrm{d}}$ & $7.3 \pm 0.8^{\mathrm{a}}$ \\
p-value & 1.000 & 1.000 & $<0.0001$ & 0.438 \\
\hline
\end{tabular}

Results are means \pm standard deviations of two independent fermentations. Values in the same column with different superscripts (a, b, c and d) are significantly different $(\mathrm{p}<0.05)$.

\section{DISCUSSION}

The objective of this study was to develop acceptable and shelf stable probiotic fruit yoghurt containing ripened banana (matooke) and Lactobacillus rhamnosus yoba. Matooke was chosen because it is one of the major food crops grown in Uganda with post-harvest losses of up $22-45 \%$ (Muranga et al., 2010). There is increased interest in adding value to the cooking banana so as to minimize postharvest losses. The probiotic $L b$. rhamnosus GG was primarily selected for two reasons: accessibility and health benefits. LGG is currently readily accessible in Uganda, and other countries in a generic form, Lb. rhamnosus yoba 2012 (Kort et al., 2015). Clinical studies have confirmed that LGG is beneficial in the treatment of gastrointestinal diseases including: rotavirus diarrhea, Chlostridum 
difficile diarrhea, antibiotic induced diarrhea and travelers' diarrhea among others (Drisko et al., 2003; Guandalini, 2011; Horvath et al., 2011).

Growth of Lactobacillus rhamnosus yoba in banana yoghurts

Effectivenes of probiotic foods requires that the probiotic organism should be able to grow and survive in the selected carrier during processing, handling and storage (Franz et al., 2014). Lactobacillus rhamnosus yoba inoculated in banana yoghurts grew by $2 \log$ cycles reaching a maximum of $\log 9.94$ cfu.g ${ }^{-1}$ after 24 hours of fermentation at room temperature $\left(21-25^{\circ} \mathrm{C}\right)$. Lactobacillus rhamnosus yoba also grew in Mutandabota, a dairy product containing $14 \%$ baobab pulp from $5.8-8.8 \log$ cfu.ml ${ }^{-1}$ in 24 hours at temperature of $23-37^{\circ} \mathrm{C}$ (Mpofu, 2015). Lb. rhamnosus grew in banana yoghurt because it was cultured with $S$ thermophilus $\mathrm{C} 106$ which has the ability to digest casein and lactose thus providing fermentable sugars to the former (Kort et al., 2015). Lb. rhamnosus is also able to utilize sucrose, glucose and fructose (Hedberg $\boldsymbol{e t}$ al. 2008) which are the major sugars in ripened banana (Marriott et al., 1981).

With regards to effect of banana concentration on growth of Lactobacillus rhamnosus, all banana concentrations used in this study facilitated growth of the probiotic to the same extent as the control yoghurt. However, significantly faster rates of acidification were observed in samples containing banana puree. The increased rate of acidification could have resulted from an increase in concentration of fermentable sugars with increasing proportion of banana in the mixture. As a result, the banana yoghurts prepared in this study attained a $\mathrm{pH}<$ 4.6 and acidity of $>0.6 \%$ within 24 hours of fermentation at room temperature compared to the 32 hours taken by the control. An optimum $\mathrm{pH}$ of $4.1-4.4$ and minimum acidity of $0.6 \%$ is recommended for yoghurts since these levels of acidity facilitate coagulum development and also prevent growth of spoilage and pathogenic microorganisms (Codex Alimentarius, 2003; Downes and Ito, 2001; Kroger, 1976)

\section{Acceptability of banana yoghurt formulations}

Yoghurt containing $7.5 \%$ banana received the highest acceptability and purchase index scores although these were generally not significantly different from the control. Yousef et al. (2013) also noted that yoghurt containing $7.5 \%$ banana pulp received higher acceptability scores than that containing $10 \%$. The fact that aceptability scores for taste, aroma were not significantly different may be due to the fact that the banana flavor was 'slightly faint' as most panelists pointed out This implies that ripened cooking bananas can be incoporporated in yoghurt up to a level of $10 \%$ withouth negatively impacting on sensory appeal. However, in this study a concentration of $7.5 \%$ banana was selected for having had the highest acceptability score for appearance $(\mathrm{p}<0.05)$. At $10 \%$ concentration of banana the yoghurt became too think to drink.

\section{Composition of banana yoghurt containing $7.5 \%$ banana puree}

Addition of ripened cooking banana at a level of $7.5 \%$ did not significantly affect the proximate composition of yoghurt. The fat, ash and carbohydrate contents of banana yoghurts were similar to values previously reported for yoghurts on the Ugandan market (Mukisa and Kyoshabire, 2010). Protein content was twice as high as values previously reported by Yousef $\boldsymbol{e t}$ al. (2013) but met the Codex requirement of a minimum value of $2.7 \%$ (Codex Alimentarius, 2003). The energy content of the yoghurt was higher than values of 79 Kcal per $100 \mathrm{~g}$ reported by McCance (2002). The high energy content in this study could be attributed to addition of up to $10 \%$ sugar in the yoghurts developed in this study. Banana yoghurt had a significantly lower moisture content than the control because inclusion of ripe cooking banana increased the total solids thus resulting in lower moisture content of yoghurt as previously observed by Yousef $\boldsymbol{e t}$ al . (2013).

\section{Shelf stability of probiotic banana yoghurt}

The shelf life of yoghurt is determined by changes in physical, chemical and microbiological characteristics (Memiši et al., 2014). Consumer acceptability, which is an important determinant of shelf life of yoghurt, is influenced by changes in the acidity, $\mathrm{pH}$ and sweetness (Cruz et al., 2010; Zanhi and Jideani, 2012). These characteristics should remain relatively unchanged as was observed in the current study during the three weeks of storage at $4^{\circ} \mathrm{C}$. Storage under refrigeration slows down biochemical processes thus ensuring product stability (Chandan 2014; Jay et al., 2008). More importantly, for probiotics, the products should contain a minimum of $\log 6 \mathrm{cfu}$ of the probiotic organism per $\mathrm{ml}$ or gram at the time of consumption (Tripathi and Giri, 2014). Consuming $100-1000$ $\mathrm{ml}$ per day of such a product provides the recommended daily dose (log $8-9$ cfu) essential for realizing the health benefits of probiotics (Knorr, 1998; Tripathi and Giri, 2014). A daily dose of $100 \mathrm{ml}$ of the banana yoghurt developed in this study would provide between $\log 8-\log 11$ cfu per day thus meeting the recommended daily dosage. The viable counts of Lactobacillus rhamnosus obtained in this study after three weeks of storage were below log 8 cfu. ${ }^{-1}$ that was reported by Hekmat, Soltan and Reid (2009) in yoghurt after 28 days of storage at $4{ }^{\circ} \mathrm{C}$. Hekmat et al., (2009) attributed the high survival in their study to the addition of $0.33 \%$ yeast extract in the yoghurt. Yeast extract contains high level of carbohydrates and can thus be used as a prebiotic agent to help promote bacterial growth (Hekmat et al., 2009; Yousef et al., 2013).

\section{CONCLUSION}

Lactobacillus rhamnosus yoba can be used to produce acceptable probiotic banana yoghurt at room temperature within 24 hours. The product remains stable for at least 3 weeks under storage at $4^{\circ} \mathrm{C}$. Consumption of $100 \mathrm{ml}$ of this yoghurt meets the recommended daily probiotic intake. Although addition of banana in concentration between $5-10 \%$ introduced a slight banana aroma the composition and acceptability of the yoghurt were not affected. This study illustrates the potential of reducing postharvest losses of tropical fruits by incorporating them into other value added products.

Acknowledgements: This research was funded by the Food Technology and Business Incubation Center (FTBIC), Makerere University.

\section{REFERENCES}

Codex Alimentarius. (2003). Codex Standard for Fermented Milks. CODEX STAN 243-2003. Arusha, Tanzania: Codex Alimentairus Commission.

AOAC (2000) Official methods of analysis of the association of analytical chemists. 17th ed. Gaithersburg, Maryland, USA.

Balikowa D. (2011). Dairy development in Uganda. A review of Uganda's dairy industry. Ministry of Agriculture, Animal Industry and Fisheries, Uganda; Food and Agriculture Organization of the United Nations.

Chandan, R.C. (2011), Dairy ingredients for food processing: an overview, Oxford, UK., Wiley-Blackwell. http://dx.doi.org/10.1002/9780470959169

Chandan, R.C. (2014). Dairy - Fermented Products. In: Clark, S., Jung, S. \& Lamsal, B. (eds.) Food Processing: Principles and Applications. 2nd ed. New Jersey, USA: John Wiley \& Sons, Ltd, pp $405-431$ http://dx.doi.org/10.1002/9781118846315.ch18

Cruz, A.G., Walter, E.H., Cadena, R.S., Faria, J.A., Bolini, H.M., Pinheiro, H.P \& Sant'ana, A.S. (2010). Survival analysis methodology to predict the shelf-life of probiotic flavored yogurt. Food Res Int, 43, 1444-1448. http://dx.doi.org/10.1016/j.foodres.2010.04.028

Downes, F \& Ito, K. (2001). Compendium of methods for the microbiological examinations of foods, $4^{\text {th }}$ Edition. American Public Health Association, Washington, DC, USA. http://dx.doi.org/10.2105/9780875531755

Drisko, J.A., Giles, C.K \& Bischoff, B.J. (2003). Probiotics in health maintenance and disease prevention. Altern Med Rev, 8 (2), 143-155.

FAO/WHO. (2002). Guidelines for the evaluation of probiotics in food. Food and Agriculture Organization of the United Nations and World Health Organization Working Group Report London, Ontario, Canada.

Franz, C.M., Huch, M., Mathara, J.M., Abriouel, H., BenOmar, N., Reid, G., Galvez, A \& Holzapfel, W.H. (2014). African fermented foods and probiotics. Int J Food Microbiol, $\quad 190, \quad 84-96$ http://dx.doi.org/10.1016/j.ijfoodmicro.2014.08.033

Guandalini, S. (2011). Probiotics for prevention and treatment of diarrhea. $J$. Clin. Gastroenterol, $\quad 45$, http://dx.doi.org/10.1097/MCG.0b013e3182257e98

Hedberg, M., Hasslöf, P., Sjöström, I., Twetman S \& Stecksén-Blicks C. (2008). Sugar fermentation in probiotic bacteria-an in vitro study. Oral Microbiol Immunol, 23, 482-485. http://dx.doi.org/10.1111/j.1399-302X.2008.00457.x

Hekmat, S., SoltanI H \& Reid G. (2009). Growth and survival of Lactobacillus reuteri RC-14 and Lactobacillus rhamnosus GR-1 in yogurt for use as a functional food. Innov Food Sci Emerg Technol., 10, 293-296. https://doi.org/10.1016/j.ifset.2008.10.007

Horvath, A., Dziechciarz, P \& Szajewska, H. (2011). Meta-analysis: Lactobacillus rhamnosus GG for abdominal pain-related functional gastrointestinal disorders in childhood. Aliment Pharmacol Ther, 33, 1302-1310. http://dx.doi.org/10.1111/j.1365-2036.2011.04665.x

Jay, J.M., Loessner, M.J \& Golden, D.A. (2008). Modern Food Microbiology, New York. USA, Springer Science \& Business Media.

Karamura, E., Frison, E., Karamura, D \& Sharrock, S. (1998). Banana production systems in eastern and southern Africa. Bananas and Food Security. Proceedings of an International Symposium held in Douala, Cameroon.

Knorr, D. (1998). Technology aspects related to microorganisms in functional foods. Trends Food Sci Technol, 9, 295-306. http://dx.doi.org/10.1016/S09242244(98)00051-X

Kort, R \& Sybesma, W. (2012). Probiotics for every body. Trends Biotechnol, 30, 613. http://dx.doi.org/10.1016/j.tibtech.2012.09.002

Kort, R., Westerik, N., Serrano, L.M., Douillard, F.P., Gottstein, W., Mukisa, I.M., Tuijn, C.J., Basten, L., Hafkamp, B \& Meijer WC. (2015). A novel consortium of Lactobacillus rhamnosus and Streptococcus thermophilus for increased access to functional fermented foods. Microb Cell Fact, 14, 1 http://dx.doi.org/10.1186/s12934-015-0370-x

Kroger, M. (1976). Quality of yogurt. J Dairy Sci, 59, 344-350. http://dx.doi.org/10.3168/jds.S0022-0302(76)84208-7 
Marriott, J., Robinson, M \& Karikari, S.K. (1981). Starch and sugar transformation during the ripening of plantains and bananas. J. Sci. Food Agr, 32, 1021-1026. http://dx.doi.org/10.1002/jsfa.2740321011

McCancE, W.S. (2002). McCamce and Widdowson's The Composition of Foods. 6th summary edition. Food Standards Agency. Cambridge, UK: Cambridge: Royal Society of Chemistry.

Memiši, N.R., Vesković-Moračanin, S.M., Škrinjar, M.M., Iličić, M.D \& Ač, M.Đ. (2014). Storage temperature: A factor of shelf life of dairy products. Acta Periodica Technologica, 55-66. https://doi.org/10.2298/APT1445055M

Mpofu, A. (2015). Development of probiotic mutandabota, a locally sustainable functional food incorporating Lactobacillus rhamnosus. $\mathrm{PhD}$, Wageningen University, Wageningen, The Netherlands

Mukisa, I \& Kyoshabire R. (2010). Microbiological, physico-chemical and sensorial quality of small-scale produced stirred yoghurt on the market in Kampala city, Uganda. Nutr Food Sci, 40, 409-418. http://dx.doi.org/10.1108/00346651011062069

Muranga, F.I., Kanyago, M., Nabugoomu, F \& Ntambi J.M. (2009). Investigation of the potential of fortified instant Matooke flour (ITF) in rehabilitation of malnourished children. Part II: Testing potential of ITF as a vehicle food for malnutrition intervention. Afr.J. Food Sci., 3, 279-287.

Muranga, F.I., Mutambuka, M., Nabugoomu, F \& Lindhauer M. (2010) Optimisation of raw tooke flour, vital gluten and water absorption in tooke/wheat composite bread: effect of raw tooke flour and vital gluten on wheat flour physicochemical and dough rheological properties (Part I). Afr.J. Food Sci, 4, 223-230.

Muranga, F.I., Nabugoomu, F \& Katebarirwe, J. (2011). Effect of optimal incorporation of hybrid banana flours on acceptability of soy fortified banana flour based products. Afr.J. Biotechnol, 10, 19788

Nakawesi, J.S., Wobudeya, E., Ndeezi, G., Mworozi, E.A \& Tumwine, J.K (2010). Prevalence and factors associated with rotavirus infection among children admitted with acute diarrhea in Uganda. BMC Pediatr, 10, 69 http://dx.doi.org/10.1186/1471-2431-10-69

Saint-Eve, A., Lévy, C., Martin, N \& Souchon, I. (2006). Influence of proteins on the perception of flavored stirred yogurts. J. Dairy Sci, 89, 922-933. http://dx.doi.org/10.3168/jds.S0022-0302(06)72157-9

Tamime, A. (2002). Fermented milks: a historical food with modern applicationa review. Eur. J Clin Microbiol Infect Dis, 56, S2-S15. http://dx.doi.org/10.1038/sj.ejen.1601657

Tripathi, M \& Giri S. (2014). Probiotic functional foods: Survival of probiotics during processing and storage. J. Funct Foods, 9, 225-241. http://dx.doi.org/10.1016/j.jff.2014.04.030

Yousef, M., NateghI, L \& Azadi, E. (2013). Effect of different concentration of fruit additives on some physicochemical properties of yoghurt during storage. Ann Biol Res, 4, 244-249.

Zanhi, N.K \& Jideani, I.A. (2012). Physico-chemical and sensory qualities of soy and milk solids fortified low fat yoghurt. Afr. J. Agric. Res, 7, 5336-5343. http://dx.doi.org/10.5897/AJAR11.449 